\title{
The Microhistological Technique: Testing Two Central Assumptions In South-Central New Mexico
}

\section{K.M. HAVSTAD and GARY B. DONART}

Highlight: Two central assumptions of the microhistological technique were tested for their accuracy. The estimation of particle density by relative frequency proved to be accurate for equal-sized plant fragments. Ratios of identifiable to nonidentifiable fragments were neither equal to one nor equal between grass and forb fragments.

Analysis of the botanical content of diets of livestock, big game, small mammals, and insects has become common in research. The better known dietary analyses utilize either stomach, fecal or esophageal fistula samples. The respective advantages and disadvantages of these procedures have been recognized, and the use of a particular procedure is dictated by the type of study, subject animal, available facilities, time, manpower, and information desired.

Methods for quantifying the diet sample obtained by an analytical procedure have been generalized as visual appraisal, manual separation, microhistological techniques, and microscope point techniques (Theurer et al. 1976). Of these general categories, visual appraisal and manual separation are limited by the ability of the researcher to quantify individual species in the sample diet. Hence, these methods may contain large inherent personal errors. The microscope point techniques require statistical regression procedures, determination of species weight/volume relationships, and overestimation correction tactors. The microhistological techniques have become the most favored method. Sparks and Malechek (1968) have outlined the basic procedure for this method. However, its accuracy in determining dry-weight composition of masticated forage samples was not examined.

The objective of this study was to examine two central assumptions of the microhistological technique and determine if these assumptions were satisfied when determining dry-weight composition of masticated forage samples from blue grama (Bouteloua gracilis) foothill rangeland. These assumptions were that percent frequency can be used to estimate particle density and the percent of identifiable material is constant for each species.

\section{Methods}

Samples were collected from esophageal-fistulated steers grazing native shortgrass rangeland in south-central New Mexico. The study area was located on the Fort Stanton Experimental Ranch. The blue grama-dominated rangeland has been described by Allison et al. (1977). Dietary sampling was conducted during 1975 and 1976. Three periods representing three different plant growth stages-early summer, late summer, and mid winter-were selected for study. Handling and slide preparation of sample material as well as calculations for frequency, particle density, relative density, and percent dry-weight followed the procedure outlined by Sparks and Malechek (1968). Five slides were prepared for each sample period, and 20 systematically located fields were sampled for particle frequency and density on each slide to give 100 fields for each period. Reference material for all species present was collected during late summer. Reference slides, drawings, and photographs were utilized in identifying species within sample diets. When a particle observed in a field could not be identified, the slide was moved so that identification was improved by observing the entire particle.

This report is Journal article 651, Agricultural Experiment Station, New Mexico State Univ., Las Cruces. This study was conducted in cooperation with the Bureau of Land Management.

The authors are graduate research assistant and associate professor, Department of Animal and Range Sciences, Box 3-I, New Mexico State University, Las Cruces 88003. Manuscript received September 15, 1977.

\section{Results and Discussion}

The first assumption tested was that percent frequency can accurately estimate particle density, which then directly predicts dry-weight percent composition. This assumption allows the technician to reduce time spent per microscope field in quantifying percent composition and is critical for analyzing diets intensively and extensively. Table 1

Table 1. Dietary composition (\%) as determined by two methods.

\begin{tabular}{|c|c|c|c|c|c|c|}
\hline & \multicolumn{2}{|c|}{ Early summer } & \multicolumn{2}{|c|}{ Late summer } & \multicolumn{2}{|c|}{ Mid-winter } \\
\hline & $\begin{array}{l}\% \\
\text { rrequency }\end{array}$ & $\begin{array}{l}\text { Particle } \\
\text { density }\end{array}$ & $\begin{array}{c}\% \\
\text { Frequency }\end{array}$ & $\begin{array}{l}\text { Particle } \\
\text { density }\end{array}$ & $\begin{array}{c}\% \\
\text { Frequen }\end{array}$ & $\begin{array}{l}\text { Particle } \\
\text { density }\end{array}$ \\
\hline \multicolumn{7}{|l|}{ Grasses } \\
\hline Blue grama & 10.3 & 11.7 & 24.3 & 23.6 & 19.6 & 18.6 \\
\hline Sand dropseed & 26.4 & 25.2 & 37.7 & 35.2 & 20.4 & 29.4 \\
\hline Mat muhly & 7.8 & 8.7 & 5.2 & 5.4 & 3.5 & 4.2 \\
\hline Galleta & 0.3 & 0.3 & 0.7 & 0.8 & 5.6 & 5.7 \\
\hline Three-awns & 3.8 & 5.2 & 1.5 & 1.7 & 3.6 & 3.8 \\
\hline \multicolumn{7}{|l|}{ Forbs } \\
\hline \multicolumn{6}{|l|}{ Scarlet globe- } & 0.5 \\
\hline \multicolumn{7}{|c|}{ Carruth sage- } \\
\hline wort & 4.8 & 6.0 & 8.8 & 9.4 & 16.8 & 16.0 \\
\hline White aster & 5.2 & 5.5 & 7.3 & 7.8 & 3.5 & 4.3 \\
\hline
\end{tabular}

presents percent composition based upon percent frequency and particle density measurements for the eight main species found in these diet samples. The only large difference between the two measurements existed for scarlet globemallow (Sphaeralcea coccinea) during early summer, when this species was the major individual component of the diet, and for sand dropseed in mid-winter. Percent frequency overestimated this species dietary contribution. The prominent identifying characteristic of scarlet globemallow was a relatively large epidermally attached trichome which remained intact through the grinding process. This inability to meet the assumption of equal sized particles suggests caution when encountering particles which are relatively larger than other fragments. In all other instances, percent frequency was an accurate estimator of particle density.

The second assumption tested was that ratios of identifiable to nonidentifiable particles within a species were equal to one. This assumption assures that each species is as identifiable as all other species and the final percent composition will accurately reflect each species proportion within the diet. This does not necessarily demand ratios to equal one, but that ratios are cqual between species and between sample periods. However, it is not possible to test these ratios at the species level because some particles remained unidentified, even after the slide was moved. Ratios for forb and grass categories calculated for this study are presented in Table 2 . Large differences existed between grass and forb categories within and among sample periods. As grasses matured, individual particles became more difficult to identify. Forbs were consistently more difficult to identify

Table 2. Ratios of identifiable to nonidentifiable particles.

\begin{tabular}{lccc}
\hline & Early summer & Late summer & Mid-winter \\
\hline Grasses & 6.7 & 3.5 & 2.5 \\
Forbs & 3.1 & 1.4 & 2.0 \\
$\quad$ Total & 4.4 & 2.5 & 2.3 \\
\hline
\end{tabular}


than grasses, and forbs were easier to identify during seasons when the particular forb species selected by cattle were green and immature and leafy. These ratios indicated that forbs were underestimated in relation to the grass species. However, it was difficult to attribute the wide difference to a particular species or a group of species since a nonidentifiable fragment can be placed only in a grass or forb category. The influence of unequal ratios upon quantifying percent composition was unknown. The ratios indicate that this assumption was not satisifed.

Deardon et al. (1972) also found that a few species are improperly estimated because of cellular characteristics which are either easy or difficult to identify. Deardon et al. (1975) further tested variation in microscopically discernible characteristics and showed moss fragements were high in abundance and extremely easy to identify, thus resulting in an underestimation of other species in reindeer diet studies.

The microhistological technique, even though the most favored method, is subject to a number of assumptions. Accepting these assumptions is important for utilizing the technique. However, it should be realized that these assumptions are not always satisified. Individual values of percent composition for a species of a diet should be interpreted cautiously.

\section{Literature Cited}

Allison, C., R.D. Pieper, G.B. Donart, and J.D. Wallace. 1977. Fertilization influences cattle diets on blue grama range during drought. J. Range Manage. 30:177-180.

Deardon, B.L., R.M. Hanson, and R.E. Pegau. 1972. Plant fragment discernbility on caribou rumens. Proc. 1st Inter. Reindeer and Caribou Symp. Biol. Papers, Univ. Alaska Spec. Rep. No 1:257-277.

Deardon, B.L., R.E. Pegau, and R.M. Hanson. 1975. Precision of microhistological estimates of ruminant food habits. J. Wildl. Manage. 39:402-407.

Sparks, D.R., and J.C. Malechek. 1968. Estimating percentage dry weight in diets using a microscopic technique. J. Range Manage. 21:261-265.

Theurer, C.B., A.L. Lesperance, and J.D. Wallace. 1976. Botanical composition of the diet of livestock grazing native ranges. Univ. of Ariz. Agr. Exp. Sta. Tech. Bull. 233. 19 p. 